\section{A proposal for chemical characterisation and quality evaluation of botanical raw materials using glandular trichome microsampling of yacón (Polymnia sonchifolia, Asteraceae), an Andean medicinal plant}

\author{
Schorr, K.; Da Costa, F.B. *
}

Departamento de Ciências Farmacêuticas, Faculdade de Ciências Farmacêuticas de Ribeirão Preto, Universidade de São Paulo

\begin{abstract}
A proposal for chemical characterisation and quality evaluation of botanical raw materials by analysing the glandular trichomes from the leaves of two different populations of yacón (Polymnia sonchifolia Poeppig \& Endlicher, Asteraceae) is described. This species is an Andean medicinal plant and the tea prepared with their leaves displays hypoglycemic property. The method was based on the glandular trichome microsampling using LC/DAD. Qualitative chromatographic fingerprints of the glands were obtained by isocratic runs and then compared between the two populations, showing the same qualitative profile. The two main metabolites detected in the glands were later isolated from a leaf rinse extract by preparative separation and identified as the melampolides enhydrin and uvedalin. These compounds, subtypes of sesquiterpene lactones, were used as chemical markers. This technique is applicable to other medicinal plants and can be used for the evaluation of the quality of dried material or leaf rinse extracts.
\end{abstract}

\section{Resumo}

Neste trabalho é descrita uma proposta para a caracterização química e avaliação da qualidade de drogas vegetais através da análise de tricomas glandulares das folhas de duas populações diferentes de yacón (Polymnia sonchifolia Poeppig \& Endlicher, Asteraceae). Esta espécie é uma planta medicinal andina e o chá preparado com suas folhas apresenta propriedade hipoglicemiante. O método baseou-se na microamostragem de tricomas glandulares, empregando-se cromatografia líquida de alta eficiência e detecção por arranjo de diodos. As impressões digitais dos cromatogramas das glândulas foram obtidas em sistema isocrático e comparadas entre si, resultado em um mesmo perfil qualitativo para ambas as populações avaliadas. Os dois metabólitos principais encontrados nas glândulas foram isolados através de métodos preparativos a partir de um extrato de lavagem foliar, sendo identificados como enidrina e uvedalina. Estas substâncias, subtipos de lactonas sesquiterpênicas, foram utilizadas como marcadores químicos. Esta técnica é aplicável a outras plantas medicinais e pode ser usada para avaliar a qualidade de materiais secos ou extratos foliares.
In contrast to a few countries where plant-derived products with a high level of quality, efficacy and safety can be easily acquired by the population, in most others the situation is the opposite, scientific data being poor or absent. This lack of data can result in problems including inefficacy and adverse side effects of phytotherapeutical agents ${ }^{1}$.

Quality of raw botanical material may undergo alteration in several steps and must be evaluated prior to any statement regarding efficacy and safety. Adequate standardisation involving chemical evaluation can be performed in different ways, depending on whether or not the active compounds of the plant drug are known ${ }^{2}$. When the active principles are unknown or not yet clearly defined, marker compounds have to be established for analytical purposes ${ }^{2}$. Recent advances in analytical methods for the detection and structure determination of secondary metabolites such as the on-line techniques can be extended to the analysis of quality and standardisation of raw botanical material or herbal preparations.

Polymnia sonchifolia Poeppig \& Endlicher (Asteraceae), yacón, is a perennial herb from the Andes, grown for its inulin and fructan-reserving tuberous roots ${ }^{3}$. It is cultivated in western South America, Europe, Japan and Brazil. The tea prepared with their leaves is used as a hypoglycemic agent in traditional medicine and it was demonstrated that aqueous yacón extract produces an increase in the plasma insulin concentration $^{4}$. An earlier phytochemical investigation of the chemistry of the leaves showed the presence of sesquiterpene lactones - STL 5 .

The glandular trichome microsampling technique has been earlier described as a tool for the detection and identification of STL in special glands from Asteraceae for chemotaxonomy ${ }^{6}$ and was used in this work to obtain chromatographic fingerprint.

The glandular trichomes from the leaves of two samples of $P$. sonchifolia as well as the leaf rinse extract (LRE) showed basically the same chromatographic profile. Two compounds were chemically identified after a preparative run. Despite small quantitative divergences all the materials showed the same main secondary metabolites. The HPLC diagram of the LRE extract contain some additional minor peaks not observed in the glands, as would be expected from its different mode of preparation.

The compounds isolated from the LRE were found to be the melampolides enhydrin 1 and uvedalin 2, two STL. They were identified by means of IR, ${ }^{1} \mathrm{H}$ and ${ }^{13} \mathrm{C}$ NMR as well as COSY spectroscopy and all data are in agreement with those reported in the literature ${ }^{5}$. They were also the main metabolites in the glands of the two analysed samples, which explain the presence of a yellow solid mass in the LRE (see material and methods). The confirmation of their presence in the glands was achieved by indirect comparison of HPLC and UV-VIS/DAD data (Table 1) as well as co-injection with the reference compounds previously isolated. These two STL have been previously described in P. maculata var. maculata ${ }^{8}$ and Smallanthus sonchifolius $^{5}$ by means of classical phytochemical methods. From our previous experience, the chromatographic behaviour 
and UV-VIS/DAD data indicates that the glandular content is composed mainly of STL. This fact can also be confirmed by the IR data of the LRE. Such compounds are typical taxonomic markers in Asteraceae ${ }^{8}$ while melampolide types are one of the typical compounds of the genus Polymnia ${ }^{7}$.

In conclusion, based on the results it can be stated that although only two compounds were chemically identified in the case of the yacón glands, the qualitative chromatographic fingerprint based on LC/DAD data of glands is a fast, reliable and easy way of assessing chemical information on raw botanical materials prior to pharmacological or clinical studies. Where highly volatile components are not involved, the chemical information from dried material stored in herbaria or other plant collections can also be assessed by using this approach ${ }^{9}$.

\section{Material and Methods}

Plant material: P. sonchifolia was collected in November 1999 by K. Schorr. One sample is from a cultivated field at UNAERP, SP, Brazil. A second cultivated sample is from a field at Departamento de Horticultura do CERAT, UNESP, Botucatu, SP. Voucher specimens of each sample (FBC \# 95 and \# 101 respectively) were deposited in the SPFR herbarium at Departamento de Biologia, FFCLRP, USP, Ribeirão Preto, SP.

HPLC analyses: Shimadzu SCL 10Avp liquid chromatograph, Shimadzu SPD-M10A diode array detector (DAD), Shimadzu ODS column ( $5 \mu \mathrm{m}, 4.6 \times 250 \mathrm{~mm})$, UV detection simultaneously at 225 and $265 \mathrm{~nm}$ or DAD. IR spectra: Perkin Elmer 1420 spectrometer. NMR: Brucker DPX 400 (400 MHz for ${ }^{1} \mathrm{H}$ and 100 $\mathrm{MHz}$ for ${ }^{13} \mathrm{C}$ ); samples in $\mathrm{CDCl}_{3}$.

Collection of glands: 60 capitate glandular trichomes from airdried leaves were manually collected under a microscope with a dissecting forceps. The HPLC conditions were $55 \% \mathrm{MeOH}-\mathrm{H}_{2} \mathrm{O}$, $1.0 \mathrm{~mL} / \mathrm{min}$ (system 1) and 35\% MeCN-H ${ }_{2} \mathrm{O}, 1.3 \mathrm{ml} / \mathrm{min}$ (system 2) and 2,5-dimethylphenol (DMP) was employed as internal standard. The following chromatographic parameters were obtained for the main detected peaks: retention time relative to DMP in both solvent systems - rrt1 and rrt2, ratio of absorption of each peak between 225/265 nm - A $225 / 265$, according to ${ }^{6}$ and UV-VIS/DAD data of each individual peak.

Compound isolation: in a stainless steel tray, about $200 \mathrm{~g}$ of entire air-dried leaves of the sample FBC \# 101 were quickly and carefully rinsed one by one with $\mathrm{CH}_{2} \mathrm{Cl}_{2}$ for 20 seconds at room temperature. The LRE was filtered, concentrated, affording $3.2 \mathrm{~g}$ of crude material and re-suspended in $\mathrm{MeOH}-\mathrm{H}_{2} \mathrm{O}$ 7:3 (v/v), yielding $2.5 \mathrm{~g}$ of a cleaned-up extract. The IR spectrum of the supernatant showed an intense g-lactone carbonyl band at 1771 $\mathrm{cm}^{-1}$ indicating the presence of STL. Prior to HPLC analysis, the extract was dissolved in $\mathrm{MeOH}$ and stored in a refrigerator depositing a yellow solid mass after about 4-5 days. The solid mass was manually separated and then washed with cold $\mathrm{Et}_{2} \mathrm{O}$ affording $80 \mathrm{mg}$ of 1 as white needles (m.p. $144-148^{\circ} \mathrm{C}$ ). From this solid mass, compound 2 was isolated by HPLC. The HPLC data for 1 and 2 are trr $1=0.67$ and $1.32 ; \operatorname{trr} 2=1.75$ and $3.12 ; \mathrm{A}_{225 /}$ ${ }_{265}=85$ and 35 ; UV $\lambda_{\max }=212$ and 200 , respectively. Copies of the original spectra are obtainable from the author of correspondence.
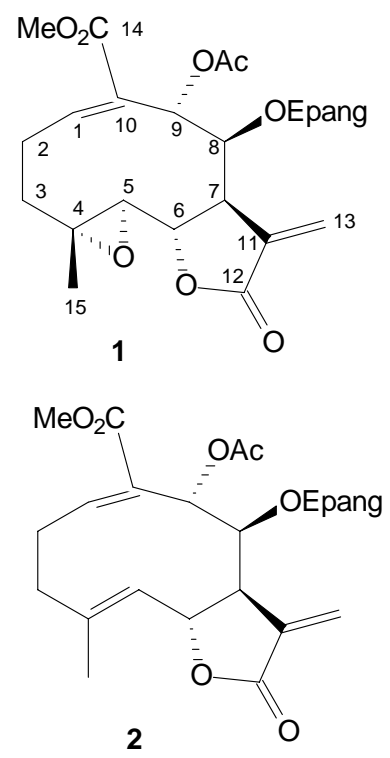

Figura 1. Chemical structures of enhydrin (1) and uvedalin (2) from $P$. sonchifolia.

\section{Acknowledgements}

The authors wish to thank FAPESP for funds and grants (\# 97/05729-4 for FBC and \# 99/02357-4 for KS), UNAERP and CERAT (Prof. Francisco L.A. Câmara) for providing the plant material as well as Prof. O. Spring for additional support. Special thanks to Prof. Benjamin Gilbert (FIOCRUZ, RJ) for the kind revision of this manuscript.

\section{References}

${ }^{1}$ Calixto, J.B. Efficacy, safety, quality control, marketing and regulatory guidelines for herbal medicines (phytotherapeutic agents). Brazilian Journal of Medical and Biological Research, v. 33, p. 179-189, 2000.

${ }^{2}$ Bauer, R.; Tittel, G. Quality assessment of herbal preparations as a precondition of pharmacological and clinical studies. Phytomedicine, v. 2, p. 193-18,1996.

${ }^{3}$ Zardini, E. Ethnobotanical notes on "yacon", Polymnia sonchifolia (Asteraceae). Economic, v. 45, p. 72-85, 1991.

${ }^{4}$ Aybar, M.J. ; Riera, A.N.S. ;Grau, A, Sanchez S.S. Hypoglycemic effect of the water extract of Smallanthus sonchifolius (yacon) leaves in normal and diabetic rats. Journal of Ethnopharmacology, v. 74, p. 125-132, 2001.

${ }^{5}$ Inoue, A.; Tamogami, S.; Kato, H.; Nakazato, Y.; Akiyama, M.; Kodama, O.; Akatsuka, T.; Hashidoko, Y. Antifungal melampolides from leaf extract of Smallanthus sonchifolius. Phytochemistry, v. 39, p. 845-848, 1995.

${ }^{6}$ Spring, O. Trichome microsampling of sesquiterpene lactones for the use of systematic studies. In: Fisher, N.H.; Isman, M.B.; 
Stafford, H.A. eds. Recent Advances in Phytochemistry Modern Phytochemical Methods, New York: Plenum Press, v. 25, p. 319-345, 1991.

${ }^{7}$ Le Van N.; Fischer, N.H. Three new melampolide sesquiterpenes, polymatin A, B and C, from Polymnia maculata Cav. var. maculata. Phytochemistry, v. 18, p. 851-854, 1979.

${ }^{8}$ Seaman F.C. Sesquiterpene lactones as taxonomic characters in the Asteraceae. Botanical Review, v. 48, p. 123-551, 1982.

${ }^{9}$ Spring, O. Chemotaxonomy based on metabolites from glandular trichomes. Advances in Botanical Research, v. 31, p. 153-174, 2000.

* Corresponding author:

Prof. Dr. Fernando B. Da Costa

Universidade de São Paulo

Faculdade de Ciências Farmacêuticas de Ribeirão Preto

Laboratório de Farmacognosia

Av. do Café s/n , 14040-903 - Ribeirão Preto - SP - Brazil

Fax: +55-16-633-1941

E-mail: febcosta@fcfrp.usp.br
Ação de extratos do açaí (Euterpe oleracea Mart.) sobre a produção de óxido nítrico em células RAW 264.7

Matheus, M.E. ${ }^{\text {; }}$ Mantovani, I.S.B. ${ }^{2}$; Santos, G.B. ${ }^{2}$; Fernandes, S.B.O.'; Menezes, F.S. ${ }^{2}$; Fernandes, P.D. ${ }^{1 *}$

1Departamento de Farmacologia Básica e Clínica, ICB, Universidade Federal do Rio de Janeiro

2Departamento de Produtos Naturais e Alimentos, Faculdade de Farmácia, Universidade Federal do Rio de Janeiro

\section{Resumo}

Açaí (Euterpe oleracea Mart.), é uma palmeira tropical muito apreciada por sua beleza e valor nutricional. Estudos químicos revelaram a presença de ácidos graxos e esteróides. No presente trabalho foi avaliada a ação de extratos obtidos dos frutos e flores sobre a produção de óxido nítrico $(\mathrm{ON})$, molécula que apresenta várias atividades fisiológicas, tais como vasodilatação, neurotransmissão, além de atividades tumoricidas e citotóxicas. Células Raw 264,7 estimuladas com lipopolissacarídeo bacteriano (LPS, $100 \mathrm{ng} / \mathrm{ml}$ ) e interferon-alfa (IFN-alfa, $10 \mathrm{U} / \mathrm{ml}$ ) produziram grande quantidade de óxido nítrico $(35 \mu \mathrm{M})$ quando comparadas com as células não estimuladas (3 $\mu \mathrm{M})$. Os extratos com hexano, diclorometano, acetato de etila e $n$-butanol apresentaram alta capacidade de inibição em células ativadas com LPS e IFN-alfa, de acordo com a concentração, sendo que na concentração mais alta ocorreu uma inibição de quase $100 \%$. Também avaliamos se o efeito inibitório seria devido a seqüestro do radical livre $(\mathrm{ON})$, através do uso do SNAP (um doador de ON). Somente o extrato em acetato de etila mostrou atividade sequestrante. Esforços estão sendo empregados na tentativa de compreender os possíveis mecanismos associados ao efeito inibitório destes extratos.

\begin{abstract}
Açaí (Euterpe oleracea Mart.) is a tropical palm tree appreciated for its attractive beauty and for nutritional purposes. Chemical studies have revealed the presence of fatty acids and steroids. In the present work, it has been tested the action of the extracts obtained from the fruits and flowers on the nitric oxide (NO) production, a very important molecule with a lot of physiological rules such as vasodilatation, neurotransmission, tumoricidal and cytotoxic activity. Cells RAW 264.7 stimulated with bacterial lipopolysaccharide (LPS, $100 \mathrm{ng} / \mathrm{ml}$ ) and interferonalpha (IFN-alpha, $10 \mathrm{U} / \mathrm{ml}$ ) produce large amounts of nitric oxide $(35 \mu \mathrm{M})$ when compared with non-stimulated cells $(3 \mu \mathrm{M})$. The hexane, dichloromethane, ethyl acetate and n-butanol extracts have shown high inhibition capacity, concentration-dependent in the cells activated with LPS and IFN-alpha, and the highest concentration has promoted almost $100 \%$ of inhibition. We also have tested if the inhibitory effect was due to a scavenger
\end{abstract}

